International Journal of Linguistics, Literature and Translation (IJLLT)

ISSN: 2617-0299 (Online); ISSN: 2708-0099 (Print)

DOI: $10.32996 / \mathrm{ijllt}$

Journal Homepage: https://al-kindipublisher.com/index.php/ijllt

\title{
Conceptualization of Metonymy Denoting Human Body Parts: (eye and hand) Idioms in English and Yemeni
}

Nabil Dhafer

Abdelmalek Essaadi University, Tétouan, Morocco

Corresponding Author: Nabil Dhafer, E-mail: nabildhafer@gmail.com

\section{ARTICLE INFORMATION}

Received: October 12, 2020

Accepted: November 10, 2020

Volume: 3

Issue: 11

DOI: 10.32996/ijltt.2020.3.11.6

\section{KEYWORDS}

Eye and hand idiom, the three mechanism: conventional knowledge, Conceptual metonymy or Conceptual metaphor

\section{ABSTRACT}

Metonymy, as a common rhetorical mode of discourse, has been extensively researched in connection with metaphor with the aim of highlighting its pragmatic function. In this assay, we begin by shedding the light on tropes (metonymy and metaphor), as previous studies showing that though both figures involve substitution of one term for another, metonymy could be contrasted with metaphor. Because idioms, as an area of language, could be based on metaphor, metonymy or conventional knowledge, then a discussion on the nature of metonymy-based idioms should be provided. This study will attempt to show that people in the Arabic(Yemeni) and English-speaking cultures share images of idiomatic expressions containing parts of the human body. This study will try to certify the claim that the figurative meaning of many idioms is predictable because their constituent parts systematically contribute to the overall figurative meaning of these expressions.

\section{Introduction}

The cognitive mechanisms, which connect the domains of knowledge to the idiomatic meanings, provide the motivation for the occurrence of particular words in several idioms. The idiomatic meaning, that is, the overall special meaning of an idiom is thus essentially provided by cognitive mechanisms, such as conventional knowledge, conceptual metonymy and metaphor.

In this study, Yemeni and English idioms containing parts of the human body ('eye', and 'hand' respectively) will be examined in order to show that their figurative meanings can be explained on the basis of the conceptual framework developed by cognitive linguistics over the past three decades (1995a, 1999, 2000, 2002; Lakoff \& Johnson 1999; Yu 1995, 1998) etc.

Friedrich U، Hans-J S (2006, p. 114-115), EYE includes properties like 'part of the body of people and animals', 'located in the head', 'organ of sight', 'locus for production of tears', we have no difficulty in interpreting any instances of the word eye as quite prototypical instances of this concept. However, sometimes it involves figurative uses of the word eye. For example, from Shakespeare's sonnets (Kerrigan, 1986): (Sometimes too hot the eye of heaven shines), the "eye" of heaven in is meant to refer to the sun. It has been argued that metonymy involves a relation of 'contiguity' (Le. nearness or neighbourhood) between what is denoted by the literal meaning of a word and its figurative counterpart and that one constituent of the metonymic link stands for the other. In contrast, metaphor has traditionally been based on the notions 'similarity' or 'comparison' between the literal and the figurative meaning of an expression. (see Lakoff \& Johnson, 1980a; Croft, 1993; Taylor, 1995; Barcelona, 2003a).

In his assay Maalej (2011) finds that (eye) is used also in Tunusian Arabic in the conceptualization of various emotions such as love (e.g. "Her father is keeping her in his eyes", "Her children are her two eyes", "Her son is the pupil of her eye"), desire (e.g. "He put his eye on her", "His eye is not in her"), anger, guilt, envy (e.g. "His eye is spicy/salty/rough", "An evil eye took him") and respect (e.g. "He is in the bigger eye"). The examples reveal that English and Arabic show similarities in terms of not only the emotion types they express via the eyes but also their conceptualizations of these emotions.

\footnotetext{
K C AL-KINDI CENTER

$\mathbf{R}$ D FOR RESEARCH AND $\mathbf{R}$ DEVELOPMENT Your gateway to world-class research
}

Published by Al-KindiCenter for Research and Development. Copyright (c) the author(s). This is an open access article under CC BY license (https://creativecommons.org/licenses/by/4.0/) 
Studies on universality, cross cultural studeis examine whether certain conceptual metaphors are used in different, especially unrelated, languages (Barcelona Sánchez 2001; Kövecses 1995a, 2000, 2002; Lakoff \& Johnson 1999; Yu 1995, 1998). Several of these and further studies deal with the conceptualization of basic concepts such as time, events, emotions, thinking, the human body, and body parts such as the hand. The main finding of these studies is that both differences and similarities can be revealed concerning conceptual metaphors and metonymies.

\section{The aim of the study}

The aim of this thesis is to survey how human-related terms and some human body parts words which talk about humanrelated terms (includes some human organ words, some body parts words and some emotional words that related to human) are used metaphorically and metonymically in different contexts in addition, the differences and similarities in both Arabic and English. In this paper, the ways in which these expressions are used to understand different target domains are discussed. The objective is to analyze from a cognitive linguistic perspective how human beings apply their bodies to understand the abstract outside world, and how those bodily experiences influence our human cognition.

\section{Research Questions}

The paper attempts to find answers to the following research questions:

1- Which are the commonly used types of metonymic expressions denoting human body parts idiom (eye and hand) in English and Arabic (Yemeni)?

2- What are the similarities and differences in semantic features between English and Arabic (Yemeni) metonymic expressions denoting (eye and hand) idiom?

3- What kind of similarities and differences are there in terms of conceptual metaphors, metonymies, and conventional/ cultural knowledge between English and Arabic (Yemeni)?

\section{Literature reviews}

Historical semanticists such as Robert Thomas (1894) uses metaphor and metonymy as terms to designate shifts in meaning across conceptual boundaries, metaphor based on subjective correspondences and metonymy based on objective correspondences; Nerlich (2010) views metaphor and metonymy as semantic changes based on transfers between conceptual spheres. Metonymy is a semantic link between two senses of a lexical item that is based on a relationship of contiguity between the referents of the expression in each of those senses." Traditionally, then, metonymy has been regarded as a stand for relation in which the name of one thing (henceforth, the source or vehicle) is used to refer to another thing (henceforth, the target) with which it is associated or to which it is contiguous.

The study of metonymy in cognitive linguistics starts with George Lakoff and Mark Johnson's influential book Metaphors We Live By (1980), in which it is claimed that metonymy, like metaphor, is not only a linguistic form but also a powerful cognitive tool for people's conceptualization of the world:" Metonymy allows us to conceptualize one thing by means of its relation to something else; metonymic concepts structure not just our language but our thoughts, attitudes, and actions; Metonymic concepts (like the part for the whole) are part of the ordinary, everyday way we think and act as well as talk". Lakoff and Johnson (1980, pp: 37).

\section{Research Methodology}

\subsection{Motivation: Conceptualizations (the three Cognitive Mechanisms)}

\subsubsection{Motivation:}

Previous studies have not yet focused on the specific subset of English human body idioms and their equivalents idioms and their conceptual motivation, and its relevance to issues of universality and alternative conceptualization. The present study complements earlier comparative studies on the use of specific human body part expressions in different languages (e.g., Kövecses 2005; Yu 2000, 2001, 2003a, 2003b, 2004). The present work also relates aspects of linguistic variation to conceptual and cultural differences, in addition to pointing to possible universalities in conceptualization and language. Both the PART FOR WHOLE metonymy and WHOLE FOR PART metonymy are conceptual in nature (Radden \& Dirven, 2007: 14).

\section{Data Representation and Analysis 6.1 Data Analysis}

The set of English idioms and its definitions in the focus of the research comes from real language data. It is taken from the Collins Cobuild Dictionary of Idioms (CDI), (1995), which gives frequency data about each idiom. Then defining human body part idiom in English and Arabic (Yemeni) according to Kövecses's (2000-2002-2004- 2005) categorization system, which is 
used as a starting point for the comparative analysis of the given database, differentiates between word forms, literal and figurative meanings, and the underlying conceptual mechanisms, the similarities and differences between them.

In this research, I am going to talk about just only two human body parts which are as follows; eye, hand. In addition, the study makes use of the literature developed in cognitive linguistics related to embodiment, the motivation of idioms, universality, and culture-specificity (e.g. Lakoff1987; Lakoff \& Johnson 1999; Gibbs 1990, 1994, 2003; Kövecses 2000, 2002, $2004,2005,2010)$. Using the cognitive linguistic framework, the analysis concerns their metaphorical and/or metonymical motivation in idioms referring to abstract concepts, such as events, actions, activities, states, emotions, and characteristics, among other things. The Yemeni equivalents of the English body part idioms are also examined with respect to their motivations as compared with their English counterparts.

\subsection{English eye idioms}

According to Kövecses (2002, pp: 150-154), metonymies can be classified into two ways: (1) either a whole standing for a part or a part standing for a whole. (2) A part stands for another part, Eyes are important body parts for seeing, and figuratively, for understanding things. As it has been often observed in the cognitive linguistic literature (Lakoff \& Johnson 1999; Kövecses 2005), the perceptual domain of seeing with the eyes is frequently and systematically used to understand the domain of knowledge, as in I see what you mean. Not only knowledge but also attention is an extremely important target domain that the domain of the eyes can help understand. The eye itself can be conceptualized as a physical object which can be manipulated by the hand. The eyes can metonymically stand for their primary function, seeing and skills. All these domains are captured by the English and Arabic Yemeni, eye idioms in the database.

\subsection{English hand idioms}

The majority of hand English human body idioms are hand idioms. This shows that our hands are very important body parts as with which we can deal with things existing in the external world. For instance, we can work or play with our hands, and we can use them in various other activities, as well. Our everyday experiences with our hands provide the cognitive basis for us to conceptualize more abstract concepts. The hand, which is most often seen as a container, is used in the conceptualization of various target domains. All these metaphors and metonymies are well grounded and go hand in hand with the conventional knowledge we have about the hand.

In addition, apart from its everyday use in Arabic language, Khadija Al-Amoudi (2013) states that the hand is associated with a great variety of meanings as can be seen in: hand, terminal part, upper limb, pointer, function, physical assistant, help, participant, a specialized person, degree of reliability, strength, force, possession... etc.

\section{The three conceptual mechanisms of eye and hand idiom}

\subsection{Conventional knowledge}

Conventional knowledge refers to the kind of everyday knowledge of particular fields that is shared by speakers of a linguistic community. This everyday knowledge about a specific body part, such as the human eye, includes our information about the parts, the shape, the size, and the function of the eye among other things, as well as the hierarchy where it belongs: the eye being a part of the face. Most often, several cognitive mechanisms contribute to the motivation of idiomatic expressions. Thus, it is possible that along with one or more conceptual metaphor, a conceptual metonymy (or several conceptual metonymies), and/or our conventional knowledge all contribute to the meaning of an idiomatic expression. This is the case, for instance, in the idiom "look someone in the eye". In addition, Kövecses (2002) defines conventional knowledge, which is the shared information that people in a particular culture have concerning a conceptual domain. It is also an important motivational force.

Eyes are important body parts for seeing, and figuratively, for understanding things. As it has been often observed in the cognitive linguistic literature (Lakoff \& Johnson 1999; Kövecses 2005), the perceptual domain of seeing with the eyes is frequently and systematically used to understand the domain of knowledge, as in I see what you mean. Not only knowledge but also attention is an extremely important target domain that the domain of the eyes can help understand.

In addition, Kovecses \& Szabo (1996) claims that the conventional knowledge on the use of the hand give rise to the idioms handful, it is a part of our everyday knowledge that the hand is too small to hold too many things easily at the same time. Our conventional knowledge about our hands involves all kinds of details about the size, the structure, the functions, the movements, the body part hierarchy it belongs to (the arm area), as well as the colour, and further characteristics of the human hand. 


\subsection{Conceptual metonymy}

According to Panther and Thornburg (2007), conceptual metonymy is a cognitive process where source content provides access to target content within one cognitive domain. In addition, Kövecses (2002) states that cognitive mechanisms may equally join and produce the motivation for the meaning of the idiom together, as in the case of gain the upper hand, where hand is motivated by the metonymy the hand stands for control, and upper is motivated by the conceptual metaphor control is up. Due to the metaphor control is a valuable possession, emerging via the use of get and gain, the ability to have control over things is seen as a valuable possession. The eye itself can be conceptualized as a physical object which can be manipulated by the hand. The eyes can metonymically stand for their primary function, seeing and skills. All these domains are captured by the English and Arabic Yemeni, eye idioms in the database.

Similar to English, all these metonymies are PART-FOR-WHOLE metonymies, in which the body part can stand for the human body or its activities, Radden and Kövecses' (1999). In relation to this point many scholars as (Lakoff \& Johnson; Kövecses) pointed out that, there are a lot of metonymical expressions of hand and studies to go along with these expressions. In the studies of idiomatic expressions of hand, metonymical expressions are more than metaphorical expressions. The previous studies for metonymy of hand, Boers (2000), Kövecses and Szabó (1996, pp: 337), Cuyskens (2001) have well-divided standpoints of metonymy. In what follows, we review a few of these expressions. THE HAND STANDS FOR PERSON, PERSONALITY/ EMOTION, ACTIVITY, SKILL, CONTROL / INFLUENCE, GIVING AND HELP.

Most importantly, eyes metonymically stand for seeing, for the whole person, for one's emotions, and for one's skills. Thus, metonymies primarily centre round the major functions of the eyes and the characteristics of the people whose body parts they are. According to Kövecses (2004) there are two major metonymies that motivate the most frequent English eye idioms. One is the metonymy eyes for seeing, according to which the body parts are often used to stand for the function they fulfil, as in all eyes are on someone. According to this metonymy, the perceptual organ, the eye, stands for the act of perception.

\subsection{Conceptual Metaphor}

Kövecses (2002/2010), Lakoff and Johnson (1980) maintain that a conceptual metaphor consists of a set of correspondences, or mappings, between a "source" and a "target" domain. The meaning of particular metaphorical linguistic expressions is based on such correspondences. So, they argued early that English has the metaphor because when we are happy, we tend to be physically up, moving around, be active, jump up and down, smile (i.e., turn up the corners of the mouth), rather than down, inactive, and static, and so forth. These are undoubtedly universal experiences associated with happiness (or more precisely, joy), and they are likely to produce potentially universal (or near-universal) conceptual metaphors.

Kövecses (2002/2010) maintains that hand metaphors and metonymies frequently deal with the concepts of control and possession. In these cases, the hand acts as a source domain to conceptualize the more abstract domains of control and possession, or the hand can be seen as a container. As a result, abstract target domains, such as events, actions, activities, states, causation, structure and organization, intensity, people, emotions, behavior, characteristics and values, power relations, knowledge, ideas, and attention, are often understood via human body parts in English, and human body parts as well as other concrete domains in Arabic. As can be seen from the cognitive mechanisms of the hands which are attached in everyday experiences they have about the uses, function, position, and shape of the hand.

In addition, Kövecses (2004) maintain that the majority of idioms are motivated by the conceptual metaphor control is holding in the hand. The idiom get your hands on somebody is motivated by the metaphor beginning to have control over somebody is putting one's hand on somebody. Consequently, the metaphor HAVING CONTROL OVER SOMEBODY IS APPLYING PHYSICAL FORCE ON HIM/HER is a well-grounded metaphor. This metaphor motivates the idiom force someone's hand.

Kövecses and Szabó (1996) maintain that most conceptual metaphors which motivate English eye idioms focus on the concept of attention, and that of knowledge. The eye, as a physical object capable of expressing one's abilities, can express one's attention paid to other entities, and one's knowledge about other entities. Because of its physical object nature eye can be viewed as an entity that can be manipulated by the hand. English and Yemeni eye idioms chiefly focus on the aspect of attention. Looking at other entities is a primary function of the eyes, and thus looking with the eyes is strongly associated with paying attention. 


\section{Eye idioms}

\begin{tabular}{|c|c|c|}
\hline NO & English idioms & Arabic idioms \\
\hline 1 & Cast your eyes on something & حط عينه عليها \\
\hline 2 & An eye for an eye & العين بالعبين \\
\hline 3 & In the public eye & في أعين الناس \\
\hline 4 & Turn a blind eye to something & كأن ماشفته \\
\hline 5 & Open the eyes of someone & فتح عينك عليه \\
\hline
\end{tabular}

\subsection{Cast your eyes on something}

\section{حط عينه عليها}

The CDI defines the meaning of this idiom as when someone casts their eyes on something or someone, they want to have or possess them. Whereas, casting an eye on something means examining it carefully and gives an opinion about it.

Our conventional knowledge about this idiom is when we cast our eyes on something means that we want to possess or buy it, it remains in our memory we can't forget it until we have it. It also refers to a person who is looking at someone or something in a way which makes it clear that the person who is looking has decided to buy that thing (car, house, land, etc.) or decided to propose marriage to the other person being looked at. Sometimes in Yemen it expresses the envy (the envy eyes).

By the metonymy the eyes stands for the person, the English idiom "Cast your eyes on something", as well as in the Arabic idiom "hat Sainuh Sliha"(literally 'focus on something to possess it '), the eyes are taken to mean the person. We know that if something happens in front of us, we are concentrated to have it and we turn our eyes towards something directly in front of someone'. Speakers of both English and Arabic seem to make sense of this idiom with the help of the conceptual metonymy the eyes stands for the person which links the literal meaning to the idiomatic one.

The more specific conceptual metaphor the eyes are containers for intentions seems to be the motivating mechanism when speakers of Arabic and English make sense of the idiomatic meaning of this idiom, which is 'to be able to predict someone's intentions/ideas/thoughts by the look of his eyes'. it seems that speakers make sense of these idioms with the help of the conceptual metonymy the eyes stands for the person eyesight, as well as with the help of the conceptual metaphor seeing is touching. The image which English and Arabic language users seem to have when they hear this idiom seems to be the actual gaze going towards and object or person and 'touching' them, staying fixed on them, trying to have them.

The two cognitive mechanisms, conceptual metaphor and metonymy, as well as the speakers' image of the situation, are very likely the combination which helps the speakers make sense of the idiomatic meaning of these expressions ('to look intently at someone/something'). In order to be able to touch what is seen, the observed conspicuous entity is metaphorically conceptualized as a physical object, which can get into physical contact with the eye. As result, paying attention to an observed entity is mainly conceptualized as physical object manipulation.

In addition, it is motivated by the metonymy eyes stands for seeing and the metaphor attention is looking. In general, eye is conceptualized as an object due to the ontological metaphor the eye is an object. This is why it is acceptable to speak about eye-objects as being cast over something. Cast represents physical actions done with the eye. The verb cast implies the summary scanning of the event, it signifies a short action.

\section{العين بالعين والسن بالسن}

In The CDI this idiom refers to a system of justice where the punishment for a crime is either the same as the crime or equivalent to it. The English idiom "an eye for an eye" has the Arabic equivalent "a/Yin ba/Yin".

According to our conventional knowledge when we say an eye for an eye means that someone committed a crime and he or she will suffer the same and will be punished on his crime, it is also a justice from Allah in holy Quran (alৎin baļin uasin basin) to punish or revenge the criminal on his crime. We also know that if people fight, one person is probably punishing the other for some wrong-doing. This conventional knowledge seems to be motivating the figurative meaning of this expression, which is 'to assault/punish someone'.

Effect for cause metonymy, the eye stands for the doing (the cause) bringing about (the effect) equivalent punishment. Also, the conceptual metonymy, the eye stands for life, in this idiom in English, Arabic, and many other languages, where the word 'eye' is taken to mean life. It is the idiom an eye for an eye, a tooth for a tooth (in Arabic alSin balSin uasin basin); literally 'an eye for an eye, a tooth for a tooth'). Speakers of many languages make sense of this idiom because they understand that the 
word 'eye' (as well as the word 'tooth') is taken to mean 'life'. On the other hand, it seems also that the conceptual metonymy the eye stands for life is important when speakers try to decipher the idiomatic meaning of this expression, which can be paraphrased as 'revenge, a punishment which is as strict as a crime'. This metonymy helps us to make sense of the idiom.

Metonymically, the eye here stands for person and punishment (part for the whole) one human body part represented as the source (eye) stands for the body part that has committed the target (the crime). Speakers of both English and Arabic seem to make sense of this idiom with the help of the conceptual metonymy the eye stands for person which links the literal meaning to the idiomatic one. That is, these body parts often stand metonymically for the actions carried out with them hence the metonymy the body part stands for the action. This is again part of the general PART-FOR-WHOLE metonymy.

Accordingly, the conceptual metaphor seeing something is being aware of something or understanding is seeing, in terms of the physical focusing of an eye while perceiving an object or punishment. It seems to be at work when speakers of English and Arabic make sense of the idiomatic meaning of this idiom, which is to make someone aware of some fact/to make someone understand'.

\subsection{In the public eye

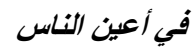

The CDI defines this idiom as a situation where many people know who they are and are aware of what they are doing, because they are famous or because they are often mentioned on television or in the newspapers. If something such as an issue is in the public eye, people are aware of it.

With respect to our conventional knowledge this idiom is used when we refer to someone who is known and famous among people or we are aware of all things about him. If all eyes are on someone or something, everyone is carefully watching that person or thing, often because they are expecting something to happen or develop.

This English idiom 'in the public eye" that has the Arabic equivalent, ' $f$ a a in alnas' 'implies that the expressions in someone's eyes can predict his intentions or aims and all things about him. This idiom invokes an image of someone's intentions or news being contained in people eyes. Another image seems to be that of someone 'reading' or being able to guess these intentions from the look on people's faces, which is 'to know and understand everything about someone.

The conceptual metonymy the eye stands for attention can also be said to motivate the idiomatic meaning of this idiom. Thus, the eye can be used to refer to the person. Thus, it can metonymically provide access to the concept of the person hence the metonymy the body part stands for the person, for example in the public eye. This is part of the very general PART-FOR-WHOLE metonymy (Lakoff\& Johnson 1980; Kövecses 2002).

The Arabic equivalent uses additional construal to depict the same situation "fi a distance instead of the container image. Famous people are seen as if they were standing, acting physically in front of the people making up the public. In addition, the Arabic word "alnas "in the sense of publicity is related to the idea of being public.

The conceptual metaphor the eyes are containers for intentions seems to be the motivating mechanism when speakers of Arabic and English make sense of the idiomatic meaning of this idiom, which is 'to know someone's intentions/ideas/thoughts/news from the looking in the people's eyes'.

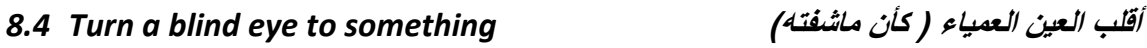

As for the CDI, this idiom refers to a situation when we ignore something because we do not want to take any action over it, even though we know that we should.

The English idiom turn a blind eye to something which finds its Arabic idiomatic equivalent in the expression kaain ma Juftah implies that the expression in turning eyes can be better sometimes than paying enough attention to getting to know things. However, and as kind of the cross-cultural differences, the English close your eyes to is understood by and equivalent to the Arabic close his/her ears or eyes to (sid ađanuh, \aino), which stands for refusing to notice or acknowledge something unwellcome or disagreeable.

With regards to our conventional knowledge about this idiom is frequently used, with the following meaning: "If you turn a blind eye to something, you deliberately ignore it because you do not want to take any action over it, even though you know you should". 
Metonymically, looking into somebody's eyes can stand for agreeing with somebody, whereas looking away usually stands for disagreeing. Besides, the metonymies blind/bare for no instruments and the eyes stands for the skills appear in this idiom to ignore someone or neglecting him. Ignorance is conceptualized as blindness, and not paying attention to something important as having an impaired vision.

The conceptual metaphor knowing is seeing is manifested in this idiom which is a widely used as a primary metaphor. On the one hand, if one's vision is impaired, he/she is not able to pay enough attention to getting to know things. On the other hand, ignorance is metaphorically seen as blindness, which is mapping of the metaphor knowing is seeing. In addition, the metaphor attention is looking is also at work here with this idiom. It is also frequently employed. In addition, the metaphor knowing is seeing and its entailments, additionally, motivate the meaning of the idiom.

Metaphorically, the group of things that get our attention is seen as a container. So, things can be either in or out of this container depending on whether they are deliberately taken into the container of our attention or not. The same conceptual mechanism motivates the idiom turn a blind eye to something, which focuses on the things left outside of this attention container. However, and as part of the cross-cultural differences, the English close your eyes to is realized by and equivalent to the Arabic close his/her ears to (sakkar ađanuh) which stands for refusing to notice or acknowledge something unwelcome or unpleasant. We avert our eyes and refuse to make eye contact for a number of reasons. Social propriety, as in the above example, is one. We may look down with sadness, down or away with shame, and away with disgust.

\subsection{Open someone's eyes}

According to the CDI, this idiom refers to the act of warning someone to become aware of things for the first time or telling him to become aware of things that you can do in a particular situation.

Our conventional knowledge also seems to motivate the idiomatic meaning of the English expression open someone's eyes, as well as of the Arabic idiom fattah Giunuh. Our experience tells us that when people are in a problem, their eyes tend to open because the facial muscles are affected by the body's awareness. The idiomatic meaning of this expression, 'to be aware', is connected with the literal meaning by people's conventional knowledge of one of the visible signs of awareness and to pay attention.

The conceptual metonymy the eyes stands for attention can also be said to motivate this idiom in English and Arabic, such as Open someone's eyes (in Arabic fattah Giunuh) meaning 'to pay attention to', or to have eyes everywhere/all over the place/to be all eye. The eye is often taken to mean the person, life, eyesight, or attention, as well as the fact that eyes are perceived as containers for emotional states or people's intentions.

This idiom is motivated by the conceptual metaphor seeing is touching. In this idiom, language users seem to have an image of their attention firmly fixed and their eyes open onto something very important to take care of it 'to pay attention to'. Consequently, it is motivated by the conceptual metaphor seeing something is being aware of something. Our experience tells us that when we try to make someone aware of something, when we attempt to make them understand or comprehend, we have to point them in the right direction, make them see the right way. In order for us to be able to do that, the other person's eyes must be fully open. This conventional knowledge, the conceptual metonymy the eyes stands for eyesight, as well as the conceptual metaphor seeing something is being aware of something seem to be at work.

Eye-based idioms that express equal meanings in English and Arabic include have eyes in the back of your head or (my head), open someone's eyes, keep your eyes open, and with your eyes closed. Have eyes in the back of your head or (my head) (lih Siun uara rasuh) symbolizes a person who seems to be able to sense or know what is happening beyond one's field of vision. Open someone's eyes (fattah Siunuh) stands for enlightening someone about certain realties, causing him/her to realize or discover something about the truth. As for keep your eyes open (xalli Giunak mifatthat), it is used to stand for the state of being on the alert or watching carefully for something. With your eyes closed (uainta myammið Sinik) metonymically describes doing something easily; without having to make much effort.

\section{English Hand idioms}

\begin{tabular}{|c|c|c|}
\hline NO & English idiom & Arabic idiom \\
\hline 1 & Have your hand tied & مكتوفي الأبِي \\
\hline 2 & Live from hand to mouth & من بإه لفهـ \\
\hline 3 & Know something like the back of your hand & أعرفه مثل قاع بإي \\
\hline 4 & Bite the hand that feeds you & بعض البي التي تطعده \\
\hline 5 & to have a dirty hands & بإه وسنة \\
\hline
\end{tabular}

74 


\subsection{Have your hands tied}

The CDI definition of this idiom shows that it is used when something such as a law is preventing you from doing or acting in the way that you want to. You have no idea, tools and equipment to do or work with.

The Yemeni equivalent of this idiom "have your hands tied "which is"maktuf ialaidin "has the same meaning. It is used to refer to a situation where the person is unable to react or do something that he desires to do. "Someone with a short hand

"(iaduh qasirah), (al-iad qasirah ualGain basirah) is used to refer to a person who is unable to do anything, and this seems to be pragmatically equivalent to the English idiom have your hands tied. It is also used to describe a person who is unable to participate in a certain activity due to lack of money, and this seems to be parallel to the English from hand to mouth.

Someone with a dry hand (eeduh naffeh) is a metonymy for stingy person.

According to our conventional knowledge, this idiom have your hands tied is said in the situation of being unable or have no freedom to do something. Someone with a short hand (eeduh gas?eereh) is used to refer to a person who is unable to do anything, and this seems to be pragmatically equivalent to the English someone's hands are tied.

Metonymically, this idiom, in both languages, is motivated by the metonymy the hand stands for person, hand implies the person's ability and freedom to do something, and when we say someone has "his hand tied" means that he has no longer this ability and freedom. It is also motivated by the conceptual metonymy, the hand stands for the activity/action. In addition, Kövecses and Szabó (1996:337) the metonymy the hand stands for control is also at work, since if a person's hands are tied, he/she is not able to control his/her activities. The hand provides a metonymic reference point to the concept of activity, more specifically, of starting, and participating in an activity. The experiential grounding of the metonymy the hand stands for (starting) the activity derives from the fact that we usually move our hands when we want to start doing something, when our hands are tied together, we naturally cannot perform any activity with them. In this particular case, is negated and renders the meaning of the idiom as 'not to be able to do anything.' This idiom is also frequently used in journalism to describe someone who cannot express his opinion freely and he is obliged to abide by some rules while writing. Furthermore, metonymically the hand can stand for control meaning 'to be completely under someone's control.

\subsection{Live from hand to mouth من بإه لفمه}

The CDI dictionary defines this idiom as when someone does not have enough money to live comfortably, and has no money left after he or she has paid for basic needs.

The Yemeni equivalent of this idiom "Live from hand to mouth"'min iadu lafmu" has the same meaning. It refers to someone who has not enough money to provide his needs and spends all his money in the essential needs.

Our conventional knowledge about the hands could be described as people's indispensable tools. We use them as instruments in all kinds of activities, including writing, holding things, manipulating things, working with our hands, we can also say that such a person lives from hand to mouth which means that he does not plan ahead but decide what to do from day to day.

The conceptual metonymy the hand stands for the skill together with this conventional knowledge seem to be the main motivation for the idiomatic meaning of the English expressions Live from hand to mouth or from hand to mouth. This expression is usually used critically or disapprovingly. It is also used to describe a person who is unable to participate in a certain activity due to lack of money, and this seems to be parallel to the English idiom from hand to mouth. The idiom here is most probably based on the metonymy the hand stands for the activity.

The metaphor possession is having holding something on the hand seems to motivate this idiom since it focuses on getting the possessed object. In addition, the metaphor the hand is a container; the hands are conceptualized as containers which can contain many entities (obligations or responsibilities in the metaphorical sense). In the metaphorical reading, the hand as a source domain item is mapped onto the target domain, what we earn, and the mouth what we consume.

\subsection{Know something like the back of your hand يعرفه مثل قاع يده}

The CDI dictionary defines this idiom as when emphasizing that we know someone or something very well or be very familiar with something. It can be a place, person, ideas and etc.

The Yemeni equivalent of this idiom "aৎrfu mivl qaSiadi" has the same meaning. It is said when we want to show that we know something or someone very well. Yet, they are different concerning one word, in Yemeni we use the word palm instead of the word back that is used in the English equivalent. This conventional knowledge helps us to link the literal meaning with 
the idiomatic meaning, which could be understood as 'to be known'. It is this subconscious conventional knowledge which helps us to understand how the human hands are conceptualized in our mind.

This idiom is motivated by the metonymy "part for the whole". In addition, the conceptual metonymy the hand stand for the person seems to act as the linking vehicle which connects the literal meaning of this idiom to its idiomatic meaning, which is 'to know him well'.

\subsection{Bite the hand that feeds you}

بيض البي التي تطعده

The CDI dictionary defines this idiom as a situation when someone is ungrateful and behaves badly towards the person who has helped or supported him, people should not break off ties with those who help them.

The equivalent Yemeni idiom of bite the hand that feeds you"iaSt aliad aldi tadGmu"has the same meaning which is the ingratitude that one shows towards those who have given him help. Metonymically, the hand stand for helping, giving and at the same time it is the affected. It also stands for control, possession, production.

The idiomatic meaning, 'from the first owner/possessor' also seems to be linked with its literal meaning by the conceptual metaphor possession is holding something in the hand. The human body is metaphorized as a container and the hand here is metaphorized as the content in the container.

There are several idiomatic expressions in both Yemeni and English which have the same meaning as break the hand that feeds you "iaksir aliad alði tadGmu "which means not to break off ties with the people who help you. There is also in Arabic an idiom that says: "uaৎalmhu alrmai kul iaumin falma iftada sa9dhu ramani" which means being ungrateful to someone who provided you with support and help.

\section{6 to have adirty hand}

According to the CDI, this idiom means that someone avoids doing physical work or the parts of a job that he considers unpleasant or distasteful.

Our conventional knowledge of people who have committed a serious crime (usually murder) and have blood on their hands are responsible of wrong doing has their dirty hand.

Metonymically, the 'hand' here stands for persons who committed bad things, or to catch someone in the act of doing something wrong or bad, mapping body terms to perceive the outside world not only to the similarities of positions, structure and shape or function of the concrete object, but to the psychological and functional similarities of the abstract objects. We can examine this kind of metaphor that the hand is the most significant organ in the human body, we often used it to refer to the key part of some abstract entities such as a matter or a problem or abstract things. It is also extended metonymically to express negative meaning, dirty hand (iadu uasixah) symbolizes a person who is not honest and does accept bribes.

The conceptual metaphor to be honest is to have clean hands helps to convey this knowledge to the figurative meaning of this idiom which is 'to be honest'. Another expression which illustrates the point is (also in Arabic as iadu uasixah; literally 'to dirty/soak one's hands') whose figurative meaning is 'to be involved in some dishonest/illegal activity'. This idiom seems to be motivated by the conceptual metaphor to be honest is to have clean hands.

There are several idiomatic expressions in both Yemeni and English which relate to honesty or the opposite. The idiom "yaduh naðifa"stands for the metaphor to be honest is to have clean hands. (Literally: 'to have clean hands'). An extension of this idiom is the expression to wash one's (dirty) hands of something. The Yemeni equivalent of this idiom "iyasil iadatuh" (literally 'to wash one's hands over something') means 'to transfer one's responsibility for one's wrong-doings to someone else so as to avoid it'. All these expressions seem to be motivated by the conceptual metaphor to be honest is to have clean hands which link their literal meaning with their figurative meaning. Our conventional knowledge about someone's regarding his behavior, thoughts, ideologies and familiarity depends on his doing in both languages.

From what is said above, we can conclude that, in both languages, these idioms are used in the same situations and motivated by the same metonymy except for the idiom"Know something like the back of your hand "'asrfu mivl qaSiadi" in which we find a slice different concerning one word, in Yemeni we use the word palm instead of back that is used in the English equivalent. It is suggested here that these mechanisms play a key role in the way in which people understand idiomatic expressions of various kinds because they are the chief link between abstraction and concrete entities in the world. 


\section{Conclusion}

The primary aim of this study has been to provide a better understanding of the metonymy that is understood as cognitive devices which provide a link between the concrete knowledge of the world people hold in their memory and the figurative meaning of a given English and Yemeni body parts idiom. To sum up the findings of the present study, it is noticed that there are similarities and differences between English and Yemeni idioms. Therefore, the main findings of the study can be summarized as follows:

First of all, during my research, making use of dictionaries and meeting some native speakers, I have noticed that most of the Yemeni body parts idioms have their corresponding idiom in the English language, and there are similarities in meaning and differences in lexis between Yemeni idioms and their corresponding equivalents in English.

Moreover, there are differences in Yemeni idioms which is lexical and cultural. While some words in Yemeni language have different meanings, their corresponding equivalents in the English language may not carry the same cultural connotations. Furthermore, the translator of the Yemeni idioms may translate a certain word which has different meanings in the wrong way by assigning a literal translation of the word.

To conclude, this study found that both metaphor and metonymy are an important motivating aspects to us to perceive ourselves and the abstract outside world. The study also demonstrates the universality and comparatively of metaphors and metonymies in human conceptual system.

\section{References}

[1] Barcelona, S, A. ( 2001). On the Systematic Contrastive Analysis of Conceptual Metaphors: Case Studies and Proposed Methodology. Publication: Applied Cognitive Linguistics, De Gruyter

[2] Boers, F. (2000). Metaphor Awareness and Vocabulary Retention. The Applied Linguistics.

[3] Collins Cobuild English Dictionary. (1995). London: Harper Collins Publishers.

[4] Deignan, A (2005). Metaphor and Corpus Linguistics. Amsterdam: John Benjamins.

[5] Dirk, G \& Hubert, C. (2007) The Oxford handbook of cognitive linguistics /Oxford University Press.

[6] Fahad. A. (2007) A Comparative Study $f$ Metaphor in Arabic and English. General Business Writing with Teaching Implications, Indiana University of Pennsylvania

[7] Friedrich, S (2006), An Introduction to Cognitive Linguistics, second edition Routledge, Chpater, 3.

[8] Gibbs, R. (1999). Speaking and thinking with metonymy. In K.-U. Panther and G. Radden (eds.) Metonymy in Language and Thought. Amsterdam: John Benjamins.

[9] Gibbs, R. (2013). Metaphoric cognition as social activity: dissolving the divide between metaphor in thought and communication. Metaphor and the Social World, p: 54-75.

[10] Gibbs, R., \& Santa. M. (2012).The unfolding of conceptual metaphors. Metaphor and Symbol, p: 305.

[11] Hussein, A. (2006). Arabic Rhetoric, A pragmatic analysis, London: Routledge.

[12] Johnson, M. (1992). Philosophical Implications of Cognitive Semantics. Cognitive Linguistics

[13] Kövecses, Z, \& Péter S. (1996). Idioms: A View from Cognitive Semantics. Applied Linguistics, 326-355.

[14] Kövecses, Z, \& Günter R. (1998). Metonymy: Developing a Cognitive Linguistic View. Cognitive Linguistics.

[15] Kövecses, Z. (2000). Metaphor and Emotion. Language, Culture, and Body in Human Feeling.Cambridge: Cambridge University Press.

[16] Kövecses, Z., Palmer, G., and Dirven, R. (2002). Language and emotion: the interplay of conceptualisation with physiology and culture. In R. Dirven and R. Pörings (eds.) Metaphor and Metonymy in Comparison and Contrast. Berlin.

[17] Kövecses, Z. (2004). Alternative conceptualization in English and Hungarian idiom, Budapest.

[18] Kövecses, Z. (2005) Metaphor in Culture. Universality and Variation. Cambridge - New York: Cambridge University Press.

[19] Kövecses, Z. (2006). Language, Mind and Culture: A Practical Introduction. Oxford University Press.

[20] Kövecses, Z. (2010). Metaphor: A Practical Introduction. 2nd edn. Oxford: Oxford University Press. p:231- 234.

[21] Lakoff, G.( 1987). Women, Fire and Dangerous Things: What Categories Reveal about the Mind. Chicago: The University of ChicagoPress.

[22] Lakoff, G. (1990). The invariance hypothesis: is abstract reason based on image schemas?' Cognitive Linguistics.

[23] Lakoff, G. and M. Johnson, (1980). Metaphors We Live By. Chicago: University of Chicago Press.

[24] Lakoff, G.( 1986). The Meanings of Literal. Metaphor and Symbolic Activity.

[25] Lakoff \& Turner. (1989). More Than Cool Reason: A Field Guide to Poetic Metaphor. Chicago: University of Chicago Press.

[26] Lakoff, G. (1993). The Contemporary Theory of Metaphor. In: Andrew Ortony (ed.). Metaphor and Thought. 2nd ed. New York: Cambridge University Press.

[27] Lakoff, G. (1994). What is a Conceptual System? In: Willis F. Overton, \& David S. Palermo (eds.). The Nature and Ontogenesis of Meaning.

[28] Lakoff, G, \& Mark J. (1999). Philosophy in the Flesh. New York: Basic Books.

[29] Maalej, Z. (2004). Figurative language in anger expressions in Tunisian Arabic: An extended view of embodiment. Metaphor and Symbol, 19, 51-75.

[30] Macmillan English Dictionary for Advanced Learners. (2007). 2nd edition, Macmillan Education, Oxford. 
[31] Oxford Advanced Learner's Dictionary. (1996). The free dictionary online.

[32] Panther, K.-U., and Thornburg, L. (2007). Metonymy. In D. Geeraerts and H. Cuyckens (eds.) The Oxford Handbook of Cognitive Linguistics. Oxford University Press.

[33] Radden, G. \& Kovecses, Z. (1999). Towards a theory of metonymy. In K. Panther \& G. Radden (Ed.), Metonymy in Language and Thought (PP.17-59). Amsterdam / Philadelphia: John Benjamins Publishing Company.

[34] Radden, G. (2000) How metonymic are metaphors. In: A. Barcelona (ed.) Metaphor and metonymy at the Crossroad: Cognitve Approaches. Berlin and New York: Mouton de Gruyter.

[35] Simawe, S. (2001). Modernism and Metaphor in Contemporary Arabic Poetry. World Literature Today.

[36] Sperber, D and Wilson, D. (2004). Relevance theory. In G. Ward and L. Horn (eds.) Handbook of Pragmatics. Oxford: Blackwell.

[37] Weinreich, U. (1969). "Problems in the Analysis of Idioms." In: JaanPuhvel (ed.).Substance and Structure of Language. Berkeley \& Los Angeles: University of California Press.

[38] Wierzbicka, A. (2007). "Bodies and their parts: An NSM approach to semantic typology." Language Sciences.

[39] Yu, N. (1998). The contemporary theory of metaphor in Chinese: A perspective from Chinese. Amsterdam: John Benjamins.

[40] Yu, N. (2009). From Body to Meaning in Culture, John Benjamins, Amsterdam and Philadelphia. 